\title{
MAJOR PATTERNS IN THE NEOLITHIC CHRONOLOGY OF EAST ASIA: ISSUES OF THE ORIGIN OF POTTERY, AGRICULTURE, AND CIVILIZATION ${ }^{1}$
}

\author{
Yaroslav V Kuzmin² • A J Timothy Jull ${ }^{3} \cdot$ G S Burr ${ }^{2}$ \\ ABSTRACT. General chronological frameworks created recently for the Neolithic complexes of China, Japan, Korea, and \\ far eastern Russia allow us to reveal temporal patterns of Neolithization, origin of food production, and the emergence of civ- \\ ilizations. Pottery originated in East Asia, most probably independently in different parts of it, in the terminal Pleistocene, \\ about 14,800-13,300 BP (uncalibrated), and this marks the beginning of the Neolithic. Agriculture in the eastern part of Asia \\ emerged only in the Holocene. The earliest trace of millet cultivation in north China can now be placed at $9200 \mathrm{BP}$, and rice \\ domestication in south China is dated to $~ 8000$ BP. Pottery in East Asia definitely preceded agriculture. The term "civiliza- \\ tion," which implies the presence of a state level of social organization and written language, has been misused by scholars \\ who assert the existence of a very early "Yangtze River civilization" at about 6400-4200 cal BP. The earliest reliable evidence \\ of writing in China is dated only to about 3900-3000 cal BP, and no "civilization" existed in East Asia prior to this time.
}

\section{INTRODUCTION}

Extensive radiocarbon dating of prehistoric cultural complexes in East Asia (including China, Japan, Korea, and the Russian Far East) provides the basis for a reliable chronological framework for the region (see summaries: Chang 1992a,b; Kuzmin 1998, 2003a; Choe and Bale 2002). This allows us to distinguish the timing of important events in prehistory, such as the emergence of pottery, the beginning of agriculture, and the rise of civilizations. In this overview, we present the stateof-the-art knowledge of these phenomena in East Asia, which took part mostly in the Neolithic. Archaeology and subsistence for this time period are based mainly on the most recent summaries (e.g. Kobayashi 2004; Bellwood 2005; Crawford 2006, 2009; Nelson et al. 2006). Also, critical evaluation of different opinions on some subjects of prehistoric chronology in East Asia is provided.

\section{TERMINOLOGY}

As a preface to this paper, it is instructive to be reminded of the biblical wisdom that states, "But let your communication be, Yea, yea; Nay, nay: for whatsoever is more than these cometh of evil" (Matthew 5:37). The implication is that without clear definitions of terms any research can become poor scholarship. Therefore, exact terminology is crucial for our purposes.

The term "Neolithization" generally means the origin and spread of the archaeological complexes belonging to the Neolithic stage in human prehistory. There are 2 major concepts of the Neolithic in Old World archaeology. From the European viewpoint (e.g. Whittle 1996), the Neolithic "package" includes cultivation of plants, animal husbandry, and the presence of pottery; although it should be noted that pottery in some parts of Europe precedes agriculture (e.g. Budja 2006). In East Asia, the term "Neolithic" means first of all the presence of pottery vessels (e.g. Chard 1974; Barnes 1999; see also Kuzmin 2006a). The intermediate understanding of the Neolithization comes from the Near East where agriculture and domestication of livestock precede the emergence of pottery, and the term "pre-pottery Neolithic" (PPN; e.g. Renfrew 2006) was coined to determine the earliest complexes with productive economies. Thus, in the East Asian case the Neolithic complexes always have pottery vessels in artifact assemblages (but see Prendergast et al. 2009:1028).

\footnotetext{
${ }^{1}$ An earlier version of this paper was presented at the 5th International "Radiocarbon and Archaeology" Symposium (Zürich, Switzerland, March 2008) but was not included in the volume of proceedings (Radiocarbon vol 51, nr 2).

${ }^{2}$ Institute of Geology and Mineralogy, Siberian Branch of the Russian Academy of Sciences, Koptyug Ave. 3, Novosibirsk 630090, Russia. Corresponding author. Email: kuzmin@fulbrightmail.org.

${ }^{3}$ Arizona AMS Laboratory, Department of Physics, University of Arizona, Tucson, Arizona 85721-0081, USA.
} 
As for "pottery" as part of Neolithic "package," we accept it as "clay that has been fashioned into a desired shape and then dried to reduce its water content before being fired or baked to fix its form" (Darvill 2002:337-8). This is different from the term "ceramic," which is used to describe "any artifact made of fired clay, belonging to pottery, figurine, or other ceramic industries" (Kipfer 2000: 103). The clay-made figurines called "ceramic objects" are well-known in the Upper Paleolithic of Eurasia (e.g. Vandiver et al. 1989) including Siberia (Vandiver and Vasil'ev 2002). This, however, does not make the pottery production as old as these complexes, about 26,000-16,000 BP. A clear separation should be distinguished between clay figurines and "utilitarian pottery" (Vandiver et al. 1989:1002).

The definition of "agriculture," which in this review is related to the emergence of a productive economy, means generally deliberate cultivation of plants that are used primarily for food. Smith (1994:18) determined domestication as "the human creation of a new form of plant and animal-one that is identifiably different from its wild ancestors and extant wild relatives." Rindos (1984:138-9) identified 3 stages of agriculture, namely incidental domestication, specialized domestication, and agricultural domestication. Only the last stage, agricultural domestication, is considered here. Harris (1996:4) is more specific on the term "food production," and in the system "plant-food production" there is the subsystem "crop-production dominant" with "agriculture based largely or exclusively on the cultivation of domesticated plants." The latest discussion on the meaning of the term "agriculture" can be found in Harris (2007).

The term "civilization" often does not have a clear definition (see discussion: Renfrew 1980:14-6). Sometimes it is too general, and not based on solid criteria; for example, it is determined as " 3 . (more usually) Civilized condition or state; a developed or advanced state of human society; a particular stage or a particular type of this" (Simpson and Weiner 1989:257). In more specific dictionaries, one can find this definition: "Civilization - complex sociopolitical form defined by the institution of the state and the existence of a distinct great tradition" (Kipfer 2000:119). We were able to find a more precise description of "civilization" in a general English dictionary: "the stage of cultural development at which writing and the keeping of writing records is attained; also: the stage marked by urbanization, advanced techniques (as of agriculture and industry), expanded population, and complex social organization" (Gove 1976:413).

Renfrew (1980) mentions state society, urbanism, and writing when discussing the criteria for a definition of term "civilization." Evidence of a written language should therefore be a necessary aspect of any ancient civilization. Jing and Campbell (2009) recently stated that 2 meanings of "civilisation" exist: the first one includes "such developments as cities, writing, metallurgy, social hierarchy, elite material culture and states," while the second is "a kind of cultural sphere in which early polities were embedded: the normative traditions, practices and symbols demarking the ordered/domesticated world from the chaos beyond" (Jing and Campbell 2009:106). In this paper, we follow the first (stricter) determination of the "civilization."

\section{IMPORTANT ISSUES IN CULTURAL CHRONOLOGY OF EAST ASIA}

\section{The Neolithization of East Asia}

The main results and problems in the determination of the timing for emergence of pottery in East Asia were reviewed by Kuzmin (2006a). His "conservative" model of the appearance of pottery based on charcoal ${ }^{14} \mathrm{C}$ dates directly associated with potsherds shows that in 3 distinct regions of East Asia, namely south China, the Japanese Islands, and the Amur River basin in the Russian Far East (Figure 1), pottery-making technologies were developed at approximately the same time, about 
13,700-13,300 uncalibrated ${ }^{14} \mathrm{C}$ yr ago (BP). Some earlier claims for pottery-bearing cultural complexes, such as the Liyuzui, Xianrendong, and Diaotonghuan sites in China; the Shimomouchi site in Japan; and the Osanni site in Korea; appear to be invalid because of 2 factors: 1) the dubious association of dated material and pottery, and 2) the paucity of published data available (Kuzmin 2006a).

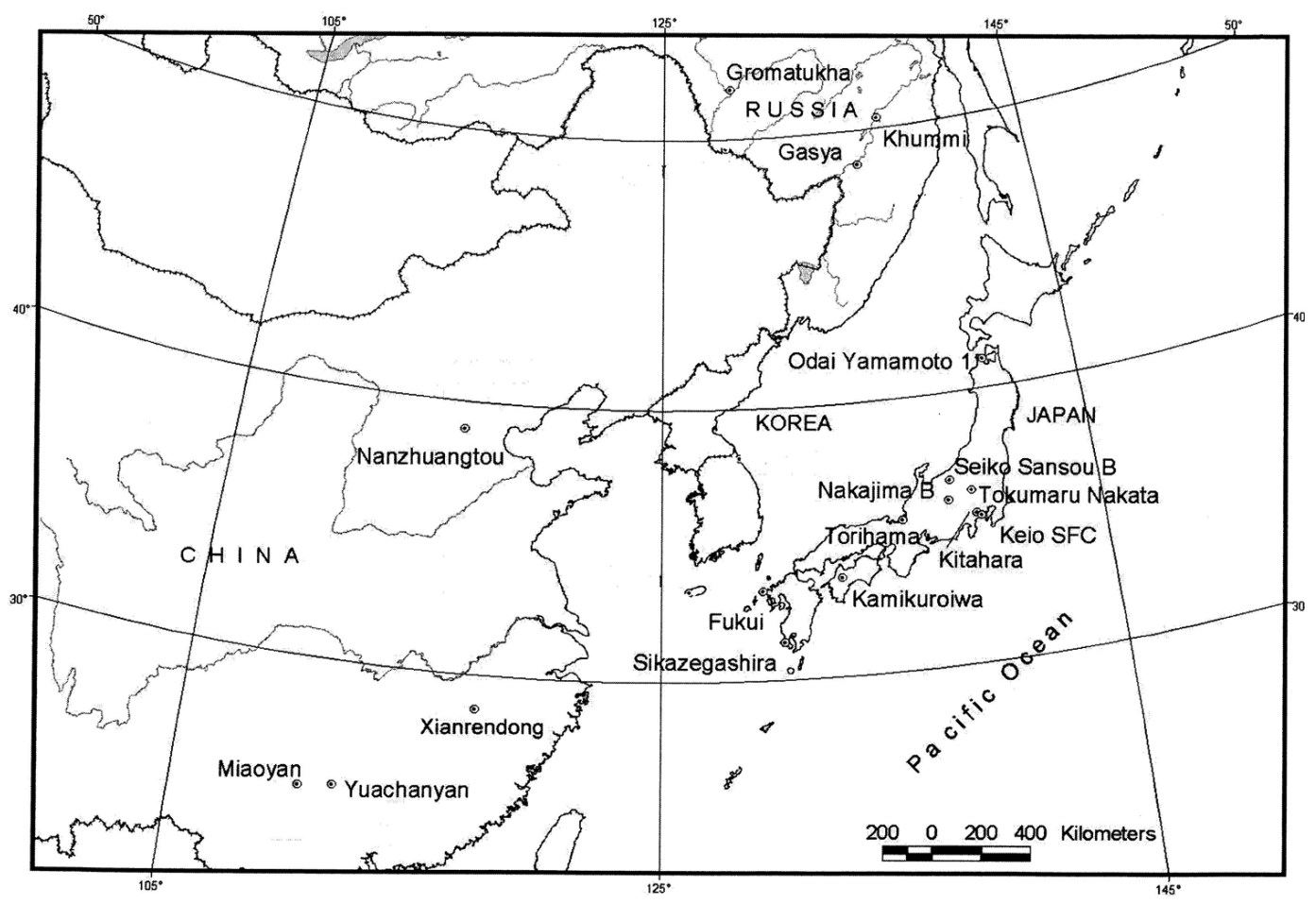

Figure 1 Archaeological sites with the earliest pottery in East Asia (after Kuzmin 2006a, with additions)

The most recent development in pottery origin in East Asia and worldwide is the determination of the age for cultural layers with potsherds at the Yuchanyan Cave in south China (Boaretto et al. 2009), and the earliest pottery here is associated with ${ }^{14} \mathrm{C}$ dates of about $14,800-14,700 \mathrm{BP}$. This, however, does not disturb Kuzmin's (2006a) model because there are no pottery sites between south China and the Russian Far East and Japanese Islands that can testify in favor of diffusion of pottery technology from a single center of origin.

Thus, the pottery from East Asia represents the oldest clay-made vessels in the world used for utilitarian purposes. The economic basis for cultural complexes with the earliest pottery, however, remains in the hunter-fisher-gatherer type (e.g. Chang 1986; Choe and Bale 2002; Kobayashi 2004; Kuzmin 2006b). The sedentary or semi-sedentary lifestyle for some of the earliest Neolithic complexes in East Asia is documented by the presence of semi-subterranean dwellings and settlements with numerous houses.

Dolukhanov and Shukurov (2004:44) assumed that pottery from the lower reaches of the Amur River is older that of the Jomon in Japan. However, this statement is not supported by primary data. For example, in Japan the earliest pottery was excavated at the Odai Yamamoto 1 site in the northern part of the Tohoku region and dated to about 13,780-12,680 BP (Taniguchi 1999; Taniguchi and Kawaguchi 2001; Nakamura et al. 2001; Kuzmin and Keally 2001; see also Kuzmin 2006a:366). 
The average age for the ${ }^{14} \mathrm{C}$ results from Odai Yamamoto 1 is around 13,500 BP (e.g. Keally et al. 2004). The earliest ${ }^{14} \mathrm{C}$ dates for pottery-associated complexes in the Amur River basin are about 13,300-12,300 BP (Kuzmin and Keally 2001; Kuzmin 2003b, 2006a; Nesterov et al. 2006). Although these values are quite close to each other, especially in the calendar timescale (Kuzmin 2006a:364, Figure 2), it is not possible to conclude that pottery from Jomon complexes is younger than that from the Lower Amur basin. Since original sources were available to Dolukhanov and Shukurov (2004) at the time of writing their paper, we do not understand how they concluded that the Amur River pottery predated the Incipient Jomon of Japan.

The spatial-temporal patterns for the process of pottery spread in Eurasia still remain unclear. The mixture of "European" (i.e. Neolithic coincides with the beginning of food production) and "Asian" (i.e. Neolithic comes along with pottery) concepts of the Neolithization and attempts to model simultaneously the spread of agriculture from the Levant to Europe and diffusion of pottery-making from East Asia toward eastern Europe (e.g. Dolukhanov and Shukurov 2004; Dolukhanov et al. 2005:1456-7; Davison et al. 2006) led to confusion because 2 different criteria of the Neolithization, agriculture and pottery, are lumped together. As a result, it is not clear which processes have been modeled. If we accept the emergence of pottery in East Asia at about 13,700-13,300 BP, its consequent spread toward the Near East and Europe cannot be currently understood due to the absence of pottery-bearing complexes between these regions. For example, the earliest pottery complexes in Siberia appeared at about 12,200-10,500 BP in the Transbaikal and possibly around 99009100 BP in the southern West Siberian Plain (see Vetrov et al. 2006; Kuzmin and Vetrov 2007:14). As for the vast terrain between these territories (several thousand kilometers), the earliest well-documented pottery assemblages are dated only to $\sim 8000$ BP (e.g. Kuzmin and Orlova 2000; Kuzmin 2007:759). Therefore, the diffusionist approach (sensu Dolukhanov and Shukurov 2004:44-5) seems to be unproductive in understanding the spread of pottery from (presumably) East Asia to other parts of Eurasia. It is quite likely that in several regions of the Old World pottery-making was invented independently (e.g. Rice 1999; see also Kuzmin 2006a:368-9).

The issue of diffusion of pottery-making technology versus independent invention in East Asia remains important. Sometimes a lack of primary data has contributed to erroneous conclusions in the literature. For example, Norton (2007:134) in Table 1, section "Neolithic-Incipient (c. 10,0008,000 B.P.)," ignore the fact that for all the sites selected (Kosanni, Donggwanjin, Sopohang, and Osanni) none have reliable ${ }^{14} \mathrm{C}$ dates, and some of them have no ${ }^{14} \mathrm{C}$ dates at all, as apparently indicated (Norton 2007:136). In the case of the Kosanni site, Choe and Bale (2002:99) published preliminary ${ }^{14} \mathrm{C}$ dates, about 10,400-10,200 BP, and the later review by Bae and Kim (2003), available to Norton at the time of writing his article, contains more ${ }^{14} \mathrm{C}$ dates from the Kosanni site, which vary greatly from $\sim 10,180$ to $\sim 4480 \mathrm{BP}$. These values, however, are not accepted as final age determinations particularly because of their large variation (Kuzmin 2006a:368). The Osanni ${ }^{14} \mathrm{C}$ date of "c. 12,000 BP" is rejected by the majority of researchers (e.g. Nelson 1993; Choe and Bale 2002:96; Kuzmin 2006a:368), so this site must also be excluded from the list of "Incipient Neolithic" of Korea. Norton $(2007: 137)$ accepts that "other sites that are proposed to date to the Incipient Neolithic either lack ${ }^{14} \mathrm{C}$ dates (e.g. Sopohang, Dongkwanjin, Imbulli) or the associated ${ }^{14} \mathrm{C}$ dates are questionable (e.g. Osanni has one ${ }^{14} \mathrm{C}$ date of c. 12,000 B.P.)." After examination of the available information, none of the "Incipient Neolithic" sites put forward by Norton (2007) can be considered wholly reliable. 


\section{Emergence of Agriculture in East Asia}

Recent progress in the study of the earliest traces of plant cultivation in East Asia, including recovery of actual seeds of cultigens, mostly broomcorn and foxtail millets (Panicum miliaceum and Setaria italica) and rice (Oryza sativa), made it possible to establish a firm chronology of the agricultural emergence in this part of the world (Figure 2). The existence in East Asia of wild progenitors for major cultivated crops, such as green foxtail (Setaria viridis) for foxtail millet (Zohary and Hopf 2000:86) and wild rice (Oryza rufipogon, O. nivara) for domestic rice (Crawford and Shen 1998; Lu 2006), testifies in favor of indigenous development of plant cultivation. The earliest solid evidence of millet cultivation in north China comes from the Cishan site in Hebei Province, and the Xinglonggou site in the Inner Mongolia Province, which belongs to the Xinglongwa cultural complex (see summaries: Crawford 2006, 2009; Lu 2006; Hunt et al. 2008; Liu et al. 2009). Direct ${ }^{14} \mathrm{C}$ dating of millet seeds at the Cishan site gave ages of about 9210-7870 BP (Table 1). The charcoal ${ }^{14} \mathrm{C}$ dates of the Xinglonggou complex are in the range of about 7300-5500 BP (Shelach 2006), although the majority of dates are of about 7300-6300 BP. The direct accelerator mass spectrometry (AMS) ${ }^{14} \mathrm{C}$ dating of broomcorn millet (Panicum miliaceum) seeds from the Xinglonggou site is currently underway and their estimated ages are from the 6th millennium BC (Lee et al. 2007).

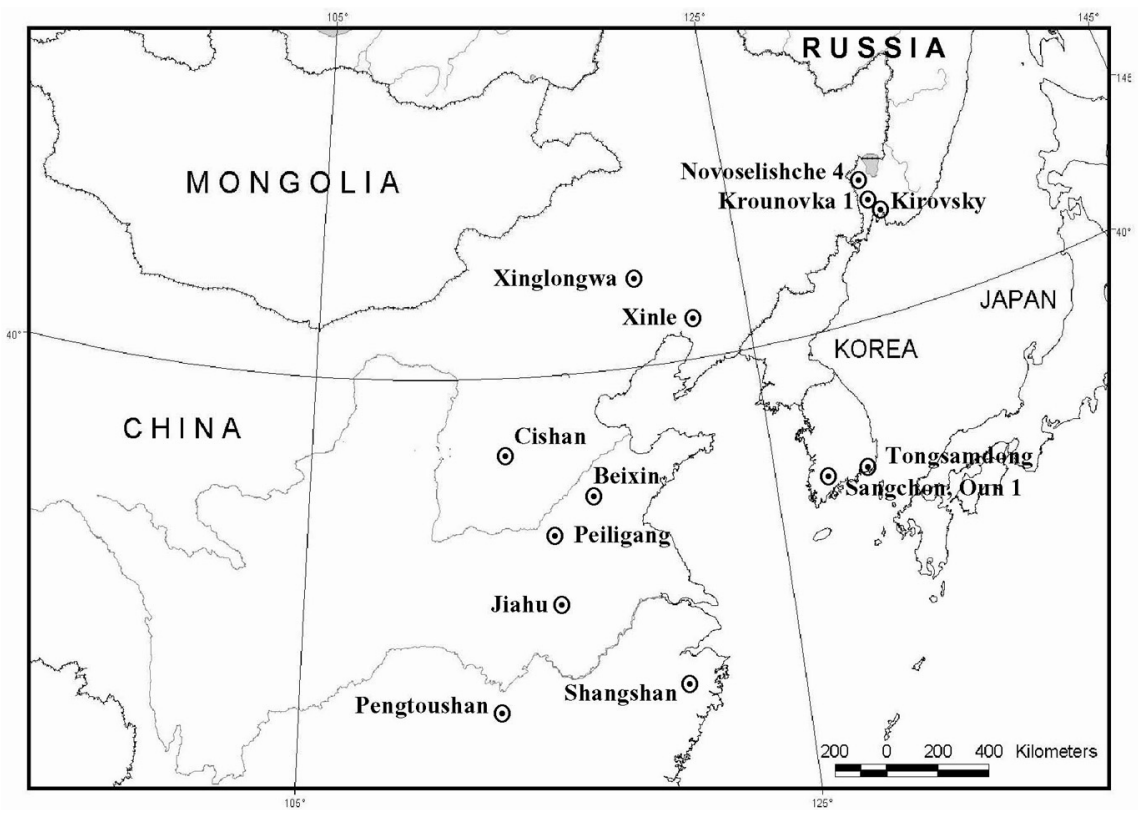

Figure 2 Archaeological sites with the earliest cultigens' finds in East Asia

It is now clear that the practice of plant cultivation was brought to the Korean Peninsula, Russian Far East, and Japanese Islands from China, beginning around 5000-4500 BP (Table 1) (Kuzmin et al. 1998; Crawford 2006; Crawford and Lee 2003; Bellwood 2005:117; Lu 2005). However, Norton (2007:135) concluded that in the Middle Neolithic of Korea (about 5500-4200 BP) there is an "early evidence for cultivated wild cereals." In the most complete source on the earliest agriculture of Korea by Crawford and Lee (2003:89), the direct AMS ${ }^{14} \mathrm{C}$ date on seeds of foxtail millet (domesticated species!) from the Tongsamdong site, $4590 \mathrm{BP}$, is presented (see Table 1). A recent re-evaluation of the process of rice domestication in eastern China allows determination of a "wild plant food production" stage (Fuller et al. 2007:325, Figure 8), which is secured by data on the morphol- 
Table 1 The ${ }^{14} \mathrm{C}$ dates associated with the earliest rice and millet agriculture in mainland East Asia (when applicable, only the earliest and latest reliable ${ }^{14} \mathrm{C}$ values are given for each cultural complex with direct evidence of agriculture).

\begin{tabular}{|c|c|c|c|c|c|}
\hline Site/Region ${ }^{\mathrm{a}}$ & $\begin{array}{l}{ }^{14} \mathrm{C} \text { date }(\mathrm{BP}) \\
(5568-\mathrm{yr} \\
\text { half-life })\end{array}$ & $\begin{array}{l}\text { Lab code } \\
\text { and } n r\end{array}$ & Material dated & $\begin{array}{l}\text { Calendar } \\
\text { age }^{\mathrm{b}} \\
(\mathrm{cal} \mathrm{BC})\end{array}$ & Reference \\
\hline Pengtoushan/S China & $7775 \pm 90$ & OxA-2210 & ice in pottery & $7020-6440$ & Crawford and $\mathrm{S}$ \\
\hline Jiahu/s & $8045 \pm$ & BK- $\mathrm{C}$ & tarcoal & $7300-6660$ & Li et a \\
\hline Jiahu/S China & $6810 \pm 130$ & DY-K-0188 & ant ash & $5980-5490$ & Li et al. 2003 \\
\hline Shangshan/S China & $8740 \pm 110^{c}$ & BA-? & Pottery temper & $8210-7590$ & Jiang and Liu 2006 \\
\hline Shangshan/S China & $8050 \pm 110$ & BA-? & Pottery temper & $7310-6660$ & Jiang and Liu 2006 \\
\hline Xinglongwa/NE China & $7250 \pm 115$ & ZK-1391 & Charcoal & $6380-5900$ & Shelach 2006 \\
\hline Xinglongwa/NE China & $5495 \pm 170$ & ZK-1389 & Bone & $4700-3970$ & Shelach 2006 \\
\hline Xinle/NE China & $6430 \pm 150$ & ZK-667 & Charcoal & $5640-5040$ & Chang 1992b \\
\hline Xinle/NE China & $5975=$ & $\mathrm{ZK}-$ & $\operatorname{arc}$ & $5210-4590$ & Chang 19 \\
\hline Peiligang/N China & $7665 \pm 480$ & $\mathrm{ZK}-$ & G1 & $7630-5570$ & Chang 1 \\
\hline & 625 & & & & $\mathrm{Ch}$ \\
\hline China & 6540 & & & 30 & Char \\
\hline China & 5480 & $\mathrm{ZK}$ & Charcoal & 980 & Char \\
\hline hina & 921 & GZ & eeds & 290 & Lu et al. \\
\hline Cishan/N China & $7870 \pm 60$ & GZ19 & Millet seeds & $7030-6600$ & Lu et al. 2009 \\
\hline Tongsamdong/Korea & $4590 \pm 100$ & TO-8783 & Millet seeds & $3630-3020$ & Crawford and $\mathrm{L}$ \\
\hline Sangchon B/Korea & $4060 \pm 140$ & TO-8608 & Millet seeds & $2920-2150$ & Crawford and Lee 2003 \\
\hline Oun $1 /$ Korea & $4030 \pm 100$ & TO-8607 & Millet seeds & $2880-2300$ & Crawford and Lee 2003 \\
\hline Kirovsky/RFE & $4150 \pm 60$ & RUL[Le]- & Charcoal & $2890-2580$ & Butomo 1965 \\
\hline ishche 4/RFE & $3840 \pm 40$ & TKa-14081 & seeds & $2460-2150$ & Sergusheva 2008 \\
\hline & 4670 & NU' & & 3620 & Komoto and Obata 2004 \\
\hline Krounovka 1/RFE & $4640 \pm 40$ & Beta-171662 & Charcoal & $3620-3350$ & Komoto and Obata 2004 \\
\hline
\end{tabular}

${ }^{\text {a}} \mathrm{S}$ China - south China; NE China - northeast China; N China - north China; RFE - Russian Far East.

${ }^{b} \pm 2 \sigma$; CALIB Rev 5.1 beta software is used for calibration (Reimer et al. 2004). Values are rounded to the next $10 \mathrm{yr}$.

${ }^{\mathrm{c}}$ This value seems to be too old compared to the rest of the ${ }^{14} \mathrm{C}$ dates associated with rice in south China.

ogy of both wild and domestic species of rice (but see Liu et al. 2007). As far as we know, similar data do not exist for Korea (e.g. Crawford 2006; Crawford and Lee 2003). Thus, the establishment of "wild cereals" cultivation in the Middle Neolithic of Korea without any factual support is unfounded. Norton (2007) rejects data on the earliest agriculture in Korea published by Crawford and Lee (2003), and this is a misinterpretation of the primary information. The statements above (Norton 2007:135) contradict what is written further on in the same article: "It is fairly well accepted that cultivated plants and agricultural techniques were present in sites on the Korean Peninsula by the advent of the Middle Neolithic (c. 5500-4200 B.P.) and possibly by the Early Neolithic (if substantiated by the findings from Osanni)" (Norton 2007:141). Foxtail and barnyard millets in the Middle Neolithic of Korea (about 5500-4200 BP) are considered as "wild cultigens" (Norton 2007: $135,138)$. The meaning of this term is unclear, especially in the light of the fact that both foxtail millet and barnyard millet are always considered as domesticated species (e.g. Zohary and Hopf 2000). Norton (2007:141) states: "large diversity of cultivated plant remains were recovered from a number of Middle Neolithic sites," meaning millets, barley, and other species. It is unclear why in another part of his article these species are called "wild cultigens."

The timing of the beginning of rice cultivation remains to some extent a controversial issue. It is generally accepted that the first domesticated rice is known from the Early Neolithic cultural complexes in the Yangtze River and Huang River basins (Pengtoushan, Jiahu, Shangshan, and Bashidang sites), dated to 8000 BP (Lee et al. 2007; Liu et al. 2007; Crawford 2006; Jiang and Liu 
2006) (see Table 1). There are also other opinions about the earlier and later domestication of rice in South China. For example, Zhao and Piperno (2000) drew conclusions about the cultivation of rice at the Diaotonghuan Cave in deposits of Zone E, in the absence of ${ }^{14} \mathrm{C}$ dates, assuming that they were as old as about 10,000-9000 BP (see also Zhao 1998). A similar age, $10,000 \mathrm{BP}$, is given for the initial rice cultivation at the Yuchanyan site (Yuan 2002). Lu et al. (2002) stated even earlier ages for the beginning of rice domestication, $\sim 13,000 \mathrm{cal} \mathrm{BP}$ (corresponding to about 11,100 BP; see Reimer et al. 2004:1052). On the other hand, Fuller et al. (2009) suggested that the full rice domestication in China only occurred after $\sim 6500 \mathrm{BP}$. It is evident that more work is needed to understand the timing, environment, and material and social contexts of the emergence of rice agriculture in East Asia.

As for the dichotomy between pottery and agriculture in East Asia, it is clear that pottery-making was invented long before plant cultivation (e.g. Lu 2006:149; see also Yasuda 2002b:128-36). For example, in north China the earliest ${ }^{14} \mathrm{C}$ date securely associated with a pottery complex comes from the Nanzhuangtou site, at $\sim 10,200$ BP (see Kuzmin 2006a). The age of millet agriculture can now be estimated in this part of East Asia as about 9200-7500 BP at the Cishan and Xinglonggou sites (e.g. Lee et al. 2007; Li et al. 2009), compared to earlier data that suggested the age of millet cultivation in northeast and north China at about 7700-6400 BP (Chang 1992a,b). In south China, the earliest Neolithic sites are dated to at least about 14,800-13,700 BP (Kuzmin 2006a; Boaretto et al. 2009), while the first reliable traces of rice agriculture are known at $~ 8000$ BP (e.g. Lee et al. 2007). The attempts to connect rice cultivation and the emergence of pottery (e.g. MacNeish et al. 1998) are not supported by finding of seeds of fully domesticated rice dated to the time period when pottery manufacture began.

\section{The Earliest East Asian Civilizations: Views Pro and Contra}

By accepting written language as a mandatory criterion for determination of ancient civilization (see Terminology), the Near East becomes the region with the earliest evidence of this phenomenon. This opinion can be found in general and specialized literature. For example, McNeill (2003:3) highlighted that "scholars nearly all agree that the earliest civilization of which we have knowledge arose among Sumerians in Mesopotamia." Schmandt-Besserat (1996:762) is more specific on this subject: "Concerted archaeological and epigraphic research has identified the fountainheads of writing and established the stages of development of various scripts. Accordingly, scholars have determined that writing has been invented independently in three places. The people of Sumer, in the ancient Near East-present-day Iraq — created the first script around 3100 B.C. Chinese script appeared about 1500 B.C. and in Mesoamerica writing existed ca. 300 B.C."

Therefore, Mesopotamia is the place with the earliest civilization in the world, sensu stricto. The following examples are the Egyptian and Harappa civilizations, dated to about 3100-3000 BC and about 2500-2000 BC, respectively; and Crete at 2200 BC (e.g. Cotterell 1980; Ehrich 1992) (Figure 3). For the territory of modern China, the earliest traces of written language are known at the sites of the first Chinese states, Xia, Shang, and Zhou (Figure 3), which are traditionally dated to about 3900-3000 cal BP (or about 1950-1050 cal BC) (e.g. Schmandt-Besserat 1996:762). Recent extensive ${ }^{14} \mathrm{C}$ dating of archaeological sites belonging to these states broadly confirmed their historical dates, around 2100-1600 BC for Xia, 1600-1050 BC for Shang, and about 1050-770 BC for Zhou (Guo et al. 2000; Lee 2002:25-8; Liu et al. 2005). The earlier evidence of some kind of writing in China (which do not represent written language, however!) goes as far back as the 7th millennium $\mathrm{BC}$ at the Jiahu site ( $\mathrm{Li}$ et al. 2003); nevertheless, proper written records are dated to much later times. The most optimistic view about the existence of writing in China recently expressed by $\mathrm{Li}$ et 
al. (2003:39-40) is that it might be dated to the Late Neolithic complexes, Liangzhu, Longshan, and late Dawenkou, about 4300-2000 BC. However, these cultural complexes are definite pre-state social structures, and they do not fit the definition of "civilization."

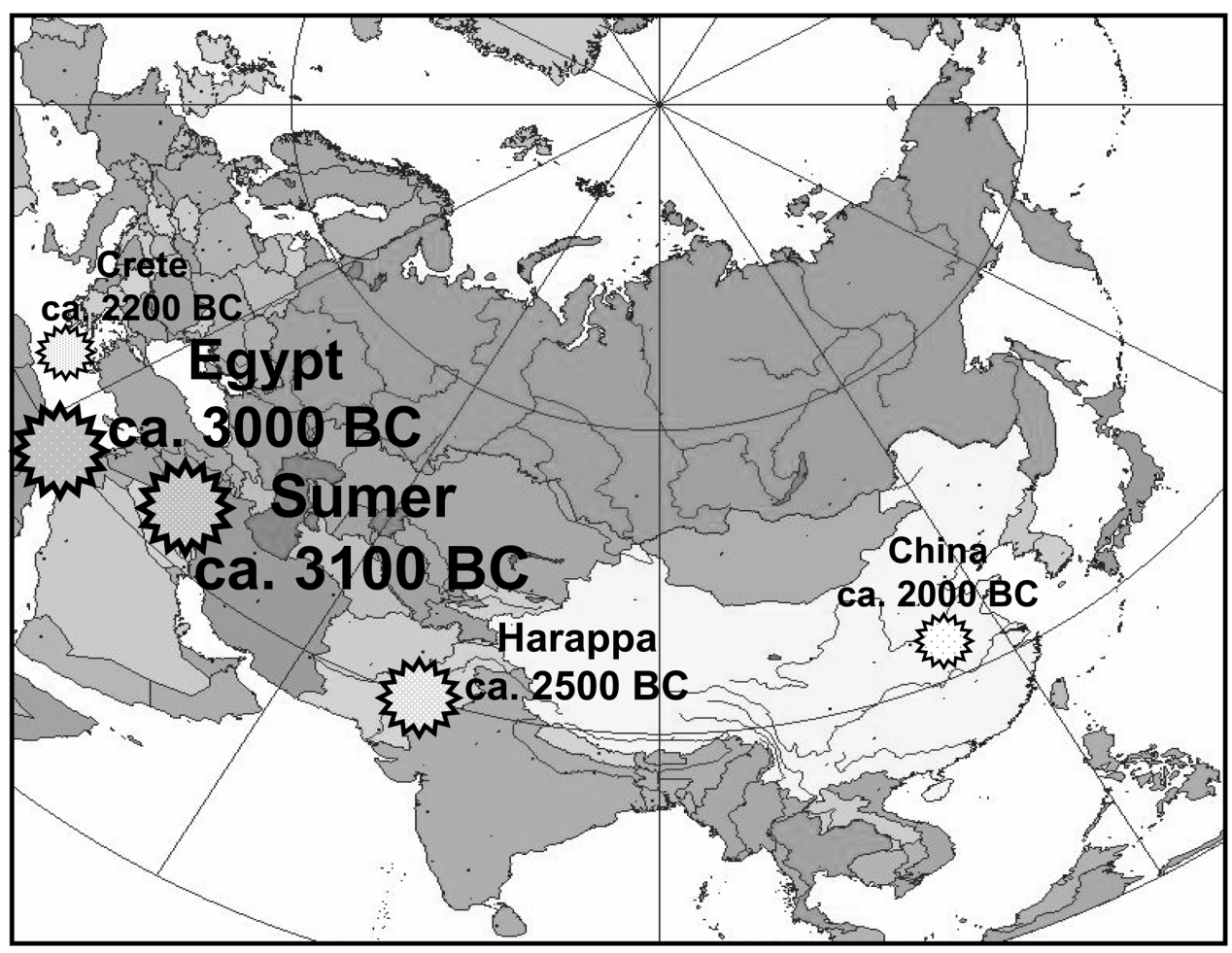

Figure 3 The earliest civilizations in the Old World

In the last 10-15 yr, the concept of "Yangtze River civilization," which existed at about 6400-4200 cal BP (about 4500-2300 cal BC), was put forward (e.g. Yasuda et al. 2003). The definition of "civilization" in this viewpoint is quite loose; it is stated that the Yangtze River civilization precedes "subsequent Chinese civilization" (Yasuda et al. 2003:149) and that the Yangtze River civilization was "created by rice-cultivating farmers and fishers" (Yasuda et al. 2003:150). Also, Yasuda (2002a: 16) state that "it is not wise to use literally the development model proposed for the West Asian region to explain the civilizational processes in the East. Yasuda (1997) started using the term "Jomon civilization," which will enable re-evaluation of the civilizational processes from a different perspective. Because of different ecological conditions and various other factors, the East Asian region will have to be treated differently from the Western world." The supposed "Jomon civilization" is dated to about 5500-4500 BP and was based on chestnut production (e.g. Yasuda 2002a; Kitagawa and Yasuda 2003). Yan (2002:156) pointed out that "the origin of the state of China and Chinese civilization can be traced to the Longshan period around 5000 yrs. BP." The reason given for this conclusion is the existence of large cities in the Longshan culture (Yan 2002:155-6).

The "logic" in the determination of the "Yangtze River civilization" and "Jomon civilization" seems to have unrecoverable defects. If we accept the urbanism (in the form of walled settlements) and agriculture, the Jericho site in the Levant with cereal cultivation dated to $\sim 8500 \mathrm{BC}$ (e.g. Ehrich 1992) should be considered as the first "civilization" known in the world! However, such a conclu- 
sion was never put forward, to the best of our knowledge (see e.g. Renfrew 1980:13). To us, the creation of the concept of Oriental "civilizations" is to some extent a nationalistic step toward the approval of their existence in East Asia prior to the emergence of the first states in West Asia, such as Sumer, Egypt, and Harappa. The final development of this line of thought is the "Circum-Pacific life civilizations" (Flenley and Yasuda 2008). Unfortunately, the definition of "civilization" in Yoshinori Yasuda's case does not satisfy scientific criteria and cannot be accepted as a reliable and uniformly applicable concept.

Yasuda (2002c:357-62), upon acceptance of a quite early age of the rice domestication in south China, older that 10,000 cal BP, states: "it is now clear that the domestication of wheat and rice began more or less simultaneously in West and East Asia. In both regions the agriculture originated concurrently and developed even without any kind of inter-relationship. We must also note that the 'East Asian Fertile Crescent of Rice' is far more respectable older that the 'West Asian Fertile Crescent of Wheat.' Therefore, the conventional monistic historical view of civilization development, which states that the 'West Asian Fertile Crescent of Wheat' spawned agriculture and civilization which then spread to Egypt, Indus and finally to East Asia, does not hold good any more. It could only be applicable to some parts of West Asia or Europe but not everywhere. It seems that there were certainly more than one centres of the origin of agriculture, domestication of animals, development of pyrotechnologies and eventually civilizations. Hence the pluralistic view of civilization appears to be applicable to different regions of the world." This rather lengthy quotation is necessary to show that here there is definite mixture of apples and oranges, i.e. agriculture and civilization. Also, no citation is given about who expresses "conventional monistic historical view of civilization development." To the best of our knowledge, serious researchers never derived the origins of agriculture and civilization in China from the West Asia (e.g. Renfrew 1980, 1996; Bellwood 2005). Therefore, the whole statement above by Yasuda (2002c) is misleading.

\section{CONCLUSION}

Critical review of some of the most important issues in the prehistoric cultural chronology of East Asia allows us to conclude that the "East Asian" concept of Neolithization is quite different from 2 other major models, "Levantine" and "European." In East Asia, the emergence of pottery in the Late Glacial hunter-gatherers continuum at about14,800-13,300 BP may be considered as the intensification of plant and freshwater resource utilization. Agriculture in East Asia developed later; in regions like China, on the order of $5000 \mathrm{yr}$ after the invention of clay vessels, and in other areas (Japan and the Russian Ear East) even later, up to $9000 \mathrm{yr}$ after initial pottery production. This shows that the relationship between "pottery" and "agricultural" trajectories of Neolithization is quite complex. As for the earliest civilization in East Asia, it is related to the earliest states in central China-Xia, Shang, and Zhou—and is dated to about 2100-2000 BC. Several civilizations in the Near East and Indus River valley are definitely older than those in China, and attempts to define a "Yangtze River civilization" dated to about 4500-2300 BC do not conform to a clear and uniform definition of "civilization," as applied elsewhere. The "Yangtze River civilization" must have occurred much later and should not be related to the early human history in East Asia.

\section{ACKNOWLEDGMENTS}

This research emerged from long-term collaboration between the coauthors, which began in the mid-1990s. Throughout these years, it was partly supported by several grants, mainly from US NSF (EAR 92-03883, 95-08413, 97-30699, and 01-15488); US Fulbright Program (96-21230 and 0327672); Russian Foundation for Basic Sciences (94-05-16049, 96-06-80688, 99-06-80348, 02-06- 
80282, and 06-06-80258); and the Japan Foundation and Korea Foundation. Numerous colleagues from Russia, USA, Japan, Republic of Korea, Canada, UK, China, and Slovenia, were helpful in collecting additional data that are part of this review. We are deeply grateful to them for continuous cooperation. We thank Prof O Bar-Yosef (Harvard University) for useful suggestions and comments on the earlier version of the paper.

\section{REFERENCES}

Bae K, Kim JC. 2003. Radiocarbon chronology of the Palaeolithic complexes and the transition to the Neolithic in Korea. The Review of Archaeology 24(2): 46-9.

Barnes GL. 1999. The Rise of Civilization in East Asia: The Archaeology of China, Korea and Japan. London: Thames \& Hudson. 288 p.

Bellwood PS. 2005. First Farmers: The Origins of Agricultural Societies. Malden: Blackwell. 360 p.

Boaretto E, Wu X, Yuan J, Bar-Yosef O, Chu V, Pan Y, Liu K, Cohen D, Jiao T, Li S, Gu H, Goldberg P, Weiner S. 2009. Radiocarbon dating of charcoal and bone collagen associated with early pottery at Yuchanyan Cave, Hunan Province, China. Proceedings of the National Academy of Sciences of the USA 106:9595600.

Budja M. 2006. The transition to farming and the ceramic trajectories in Western Eurasia: from ceramic figurines to vessels. Documenta Praehistorica 33:183201.

Butomo SV. 1965. Radiocarbon dating in the Soviet Union. Radiocarbon 7:223-8.

Chang KC. 1986. The Archaeology of Ancient China. 4th edition. New Haven: Yale University Press. 450 p.

Chang KC. 1992a. China. In: Ehrich RW, editor. Chronologies in Old World Archaeology. 3rd edition. Volume 1. Chicago: University of Chicago Press. p 409 15.

Chang KC. 1992b. China. In: Ehrich RW, editor. Chronologies in Old World Archaeology. 3rd edition. Volume 2. Chicago: University of Chicago Press. p 385404.

Chard CS. 1974. Northeast Asia in Prehistory. Madison: University of Wisconsin Press. 214 p.

Choe CP, Bale MT. 2002. Current perspectives on settlement, subsistence, and cultivation in prehistoric Korea. Arctic Anthropology 39(1-2):95-121.

Cotterell A, editor. 1980. The Encyclopedia of Ancient Civilizations. London: Windward. 367 p.

Crawford GW. 2006. East Asian plant domestication. In: Stark MT, editor. Archaeology of Asia. Malden: Blackwell. p 77-95.

Crawford GW. 2009. Agricultural origins in North China pushed back to the Pleistocene-Holocene boundary. Proceedings of the National Academy of Sciences of the USA 106:7271-2.

Crawford GW, Lee G-A. 2003. Agricultural origins in the Korean Peninsula. Antiquity 77(295):87-95.
Crawford GW, Shen C. 1998. The origins of rice agriculture: recent progress in East Asia. Antiquity 72(278): 848-66.

Darvill T. 2002. The Concise Oxford Dictionary of Archaeology. Oxford: Oxford University Press. 506 p.

Davison K, Dolukhanov P, Sarson GR, Shukurov A. 2006. The role of waterways in the spread of the Neolithic. Journal of Archaeological Science 33(5): $641-52$.

Dolukhanov P, Shukurov A. 2004. Modelling the Neolithic dispersal in northern Eurasia. Documenta Praehistorica 31:35-47.

Dolukhanov P, Shukurov A, Gronenborn D, Sokoloff D, Timofeev V, Zaitseva G. 2005. The chronology of Neolithic dispersal in Central and Eastern Europe. Journal of Archaeological Science 32(10):1441-58.

Ehrich RW, editor. 1992. Chronologies in Old World Archaeology. 3rd edition. Volume 2. Chicago: University of Chicago Press. 588 p.

Flenley J, Yasuda Y. 2008. Environmental variability and human adaptation in the Pacific Rim and the sustainability of the Islands. Quaternary International 184(1):1-3.

Fuller D, Qin L, Zheng Y, Zhao Z, Chen X, Hosoya LA, Sun G-P. 2009. The domestication process and domestication rate in rice: spikelet bases from the Lower Yangtze. Science 323(5921):1607-10.

Gove PB, editor-in-chief. 1976. Webster's Third New International Dictionary of the English Language (Unabridged). Springfield: G. \& C. Merriam Co. 2662 p.

Guo Z, Liu K, Lu X, Ma H, Li K, Yuan S, Wu X. 2000. The use of AMS radiocarbon dating for Xia-ShangZhou chronology. Nuclear Instruments and Methods in Physics Research B 172(1-4):724-31.

Harris DR. 1996. Introduction: themes and concepts in the study of early agriculture. In: Harris DR, editor. The Origins and Spread of Agriculture and Pastoralism in Eurasia. London: University College London Press. p 1-9.

Harris DR. 2007. Agriculture, cultivation and domestication: exploring the conceptual framework of early food production. In: Denham T, Iriarte J, Vrydaghs L, editors. Rethinking Agriculture: Archaeological and Ethnoarchaeological Perspectives. Walnut Creek: Left Coast Press. p 16-35.

Hunt HV, van der Linden M, Liu X, Motuzaite-Matuzeviciute G, Colledge S, Jones MK. 2008. Millets across Eurasia: chronology and context of early records of 
the genera Panicum and Setaria from archaeological sites in the Old World. Vegetation History and Archaeobotany 17:S5-18.

Jiang L, Liu L. 2006. New evidence for the origins of sedentism and rice domestication in the lower Yangzi River, China. Antiquity 80(308):355-61.

Jing Y, Campbell R. 2009. Recent archaeometric research on 'the origins of Chinese civilisation.' Antiquity 83(319):96-109.

Keally CT, Taniguchi Y, Kuzmin YV, Shewkomud IY. 2004. Chronology of the beginning of pottery manufacture in East Asia. Radiocarbon 46(1):345-51.

Kipfer BA, compiler. 2000. Encyclopedic Dictionary of Archaeology. New York: Kluwer Academic. 708 p.

Kitagawa J, Yasuda Y. 2004. The influence of climatic change on chestnut and horse chestnut preservation around Jomon sites in Northeastern Japan with special reference to the Sannai-Maruyama and Kamegaoka sites. Quaternary International 123-125:89-103.

Kobayashi T. 2004. Jomon Reflections: Forager Life and Culture in the Prehistoric Japanese Archipelago. Oxford: Oxbow Books. $240 \mathrm{p}$.

Komoto M, Obata H, editors. 2004. Krounovka 1 Site in Primorye, Russia. Report of Excavations in 2002 and 2003. Kumamoto: Department of Archaeology, Kumamoto University. 78 p.

Kuzmin YV, editor. 1998. Radiouglerodnaya Khronologiya Drevnikh Kultur Kamennogo Veka SeveroVostochnoi Azii [Radiocarbon Chronology of the Stone Age Cultures in Northeast Asia]. Vladivostok: Tikhookeansky Institut Geografii. 127 p. In Russian with English summary.

Kuzmin YV, editor. 2003a. The Nature of the Transition from the Palaeolithic to the Neolithic in East Asia and the Pacific. The Review of Archaeology 24(2):1-80.

Kuzmin YV. 2003b. The Paleolithic-to-Neolithic transition and the origin of pottery production in the Russian Far East: a geoarchaeological approach. Archaeology, Ethnology \& Anthropology of Eurasia 4(3)[No. 15]: 16-26.

Kuzmin YV. 2006a. Chronology of the earliest pottery in East Asia: progress and pitfalls. Antiquity 80(308): 362-71.

Kuzmin YV. 2006b. Palaeoeconomy of the Russian Far East (Stone Age complexes). In: Nelson SM, Derevianko AP, Kuzmin YV, Bland RL, editors. Archaeology of the Russian Far East: Essays in Stone Age Prehistory. BAR International Series 1540. Oxford: Archaeopress. p 167-73.

Kuzmin YV. 2007. Chronological framework of the Siberian Paleolithic: recent achievements and future directions. Radiocarbon 49(2):757-66.

Kuzmin YV, Keally CT. 2001. Radiocarbon chronology of the earliest Neolithic sites in East Asia. Radiocarbon 43(2B):1121-8.

Kuzmin, YV, Orlova LA. 2000. The Neolithization of Siberia and the Russian Far East: radiocarbon evidence. Antiquity 74(284):356-65.
Kuzmin YV, Vetrov VM. 2007. The earliest Neolithic complex in Siberia: the Ust-Karenga 12 site and its significance for the Neolithisation process in Eurasia. Documenta Praehistorica 34:9-20.

Kuzmin YV, Jull AJT, Jones GA. 1998. Early agriculture in Primorye, Russian Far East: new radiocarbon and pollen data from Late Neolithic sites. Journal of Archaeological Science 25(8):813-6.

Lee GA, Crawford GW, Liu L, Chen X. 2007. Plants and people from the Early Neolithic to Shang periods in North China. Proceedings of the National Academy of Sciences of the USA 104:1087-92.

Lee YK. 2002. Building the chronology of early Chinese history. Asian Perspectives 41:15-42.

Li X, Harbottle G, Zhang J, Wang C. 2003. The earliest writing? Sign use in the seventh millennium BC at Jiahu, Henan Province, China. Antiquity 77(29):31-44.

Liu K, Han B, Guo Z, Wu X, Yuan S, Kutschera W, Ma H, Priller A, Steier P, Wild EM, Zhao C. 2005. AMS radiocarbon dating of bone samples from the Xinzhai site in China. Radiocarbon 47(1):21-5.

Liu L, Lee G-A, Jiang L, Zhang J. 2007. The earliest rice domestication in China. Antiquity 81(313). Available at http://www.antiquity.ac.uk/ProjGall/liu1/index.html.

Liu X, Hunt HV, Jones MK. 2009. River valleys and foothills: changing archaeological perceptions of North China's earliest farms. Antiquity 83(319):82-95.

Lu H, Liu Z, Wu, NQ, Berné S, Saito Y, Liu BZ, Wang L. 2002. Rice domestication and climatic change: phytolith evidence from East China. Boreas 31(4): 378-85.

Lu H, Zhang J, Liu K, Li Y, Zhou K, Ye M, Zhang T, Zhang H, Yang X, Shen L, Zu D, Li Q. 2009. Earliest domestication of common millet (Panicum miliaceum) in East Asia extended to 10,000 years ago. Proceedings of the National Academy of Sciences of the USA 106:7367-72.

Lu TL-D. 2005. The origin and dispersal of agriculture and human diaspora in East Asia. In: Sagart L, Blench R, Sanchez-Mazas A, editors. The Peopling of East Asia: Putting Together Archaeology, Linguistics, and Genetics. New York: Routledge. p 51-62.

Lu TL-D. 2006. The occurrence of cereal cultivation in China. Asian Perspectives 45(2):129-58.

MacNeish RS, Cunnar G, Zhao Z, Libby JG. 1998. Re-revised Second Annual Report of the Sino-American Jiangxi (PRC) Origin of Rice Project SAJOR. Andover: Andover Foundation for Archaeological Research, Ltd. 129 p.

McNeill WH. 2003. Civilization. In: The Encyclopedia Americana. International Edition. Volume 7: Civilization to Coronium. Danbury: Grolier Inc. p 1-6.

Nakamura T, Taniguchi Y, Tsuji S, Oda H. 2001. Radiocarbon dating of charred residues on the earliest pottery. Radiocarbon 43(2B):1129-38.

Nelson SM. 1993. The Archaeology of Korea. Cambridge: Cambridge University Press. 307 p. 
Nelson SM, Derevianko AP, Kuzmin YV, Bland RL, editors. 2006. Archaeology of the Russian Far East: Essays in Stone Age Prehistory. BAR International Series 1540. Oxford: Archaeopress. $191 \mathrm{p}$.

Nesterov SP, Sakamoto M, Imamura M, Kuzmin YV. 2006. The Late-Glacial Neolithic complex of the Gromatukha site, Russian Far East: new results and interpretations. Current Research in the Pleistocene 23: 46-9.

Norton CJ. 2007. Sedentism, territorial circumscription, and the increased use of plant domesticates across Neolithic-Bronze Age Korea. Asian Perspectives 46(1): 137-65.

Prendergast ME, Yuan J, Bar-Yosef O. 2009. Resource intensification in the Late Upper Paleolithic: a view from southern China. Journal of Archaeological Science 36(4): 1027-37.

Reimer PJ, Baillie MGI, Bard E, Bayliss A, Beck JW, Bertrand CJH, Blackwell PG, Buck CE, Burr GS, Cutler KB, Damon PE, Edwards RL, Fairbanks RG, Friedrich M, Guilderson TP, Hogg AG, Hughen KA, Kromer B, McCormac G, Manning S, Bronk Ramsey C, Reimer RW, Remmele S, Southon JR, Stuiver M, Talamo S, Taylor FW, van der Plicht J, Weyhenmeyer CE. 2004. IntCal04 terrestrial radiocarbon age calibration, 0-26 cal kyr BP. Radiocarbon 46(3):1029-58.

Renfrew C. 1980. The emergence of civilization. In: Cotterell A, editor. The Encyclopedia of Ancient Civilizations. London: Windward. p 12-20.

Renfrew C. 1996. Language families and the spread of farming. In: Harris DR, editor. The Origins and Spread of Agriculture and Pastoralism in Eurasia. London: University College London Press. p 70-92.

Renfrew C. 2006. Inception of agriculture and rearing in the Middle East. Comptes Rendus Palevol 5(1-2): 395-404.

Rice PM. 1999. On the origins of pottery. Journal of Archaeological Method and Theory 6:1-54.

Rindos D. 1984. The Origins of Agriculture: An Evolutionary Perspective. Orlando: Academic Press. 325 p.

Schmandt-Besserat D. 1996. Writing: Introduction. In: Fagan BM, editor-in-chief. The Oxford Companion to Archaeology. New York: Oxford University Press. p 761-3.

Sergusheva EA. 2008. Ispolzovanie Rastitelnykh Resursov Naseleniem Primorya v Epokhu Neolita - Rannego Metalla (po Arkheobotanicheskim Dannym Poseleniy) [The Use of Plant Resources by Population of Primorye in the Neolithic and Early Metal Epochs (According to Archaeobotanical Data from Settlements)]. Synopsis of Candidate of Historical Sciences Dissertation. St. Petersburg: Institut Istorii Materialnoi Kultury. 24 p. In Russian.

Shelach G. 2006. Economic adaptation, community structure, and sharing strategies of households at early sedentary communities in Northeast China. Journal of Anthropological Archaeology 25(3):318-45.
Simpson JA, Weiner ESC, preparers. 1989. The Oxford English Dictionary. 2nd edition. Volume 3. Cham Creeky. Oxford: Clarendon Press. 1143 p.

Smith BD. 1994. The Emergence of Agriculture. New York: Scientific American Library. 230 p.

Taniguchi Y. 1999. Archaeological research at the Odai Yamamoto I site. In: Odai Yamamoto I Site Excavation Team, editors. Odai Yamamoto I Iseki no Kokogaku Chosa [Archaeological Research at the Odai Yamamoto I Site]. Tokyo: Department of Archaeology, Kokugakuin University. p 135-44.

Taniguchi Y, Kawaguchi J. 2001. ${ }^{14} \mathrm{C}$ ages and calibrated dates of the oldest pottery culture in the ChojakuboMikoshiba period. Daiyonki Kenkyu 40:485-98. In Japanese with English abstract.

Vandiver PB, Vasil'ev SA. 2002. A 16,000 year-old ceramic human-figurine from Maina, Russia. In: Vandiver PB, Goodway M, Mass JL, editors. Material Issues in Art and Archaeology VI. Warrendale: Material Research Society. p 421-31.

Vandiver PB, Soffer O, Klima B, Svoboda J. 1989. The origins of ceramic technology at Dolní Věstonice, Czechoslovakia. Science 246(4933):1002-8.

Vetrov VM, Kuzmin YV, Burr GS. 2006. The FinalPleistocene pottery of Siberia: Ust'-Karenga 12 site case study. Current Research in the Pleistocene 23: 49-51.

Whittle A. 1996. Europe in the Neolithic: The Creation of New Worlds. Cambridge: Cambridge University Press. 443 p.

Yan W. 2002. The origins of rice agriculture, pottery and cities. In: Yasuda Y, editor. The Origins of Pottery and Agriculture. New Delhi: Roli Books \& Lustre Press. p 151-6.

Yasuda Y. 2002a. The second East Side story: origin of agriculture in West Asia. In: Yasuda Y, editor. The Origins of Pottery and Agriculture. New Delhi: Roli Books \& Lustre Press. p 15-38.

Yasuda Y. 2002b. Origins of pottery and agriculture in East Asia. In: Yasuda Y, editor. The Origins of Pottery and Agriculture. New Delhi: Roli Books \& Lustre Press. p 119-42.

Yasuda Y. 2002c. Shift from monistic to pluralistic view of civilization. In: Yasuda Y, editor. The Origins of Pottery and Agriculture. New Delhi: Roli Books \& Lustre Press. p 353-63.

Yasuda Y, Fujiki T, Nasu H, Kato M, Morita Y, Mori Y, Kanehara M, Toyama S, Yano A, Okuno M, Jiejun H, Ishihara S, Kitagawa H, Fukusawa H, Naruse T. 2003. Environmental archaeology at the Chengtoushan site, Hunan Province, China, and implications for environmental change and the rise and fall of the Yangtze River civilization. Quaternary International 123125:149-58.

Yuan J. 2002. Rice and pottery 10,000 yrs. BP at Yuchanyan, Dao County, Hunan Province. In: Yasuda Y, editor. The Origins of Pottery and Agriculture. New 
Delhi: Roli Books \& Lustre Press. p 157-66.

Zhao Z. 1998. The Middle Yangtze region in China is one place where rice was domesticated: phytolith evidence from the Diaotonghuan Cave, northern Jiangxi. Antiquity 72(278):885-97.

Zhao Z, Piperno DR. 2000. Late Pleistocene/Holocene environments in the middle Yangtze River valley, China and rice (Oryza sativa L.) domestication: the phytolith evidence. Geoarchaeology 15(2:203-22.

Zohary D, Hopf M. 2000. Domestication of Plants in the Old World. 3rd edition. New York: Oxford University Press. 316 p. 